\section{The Dying Human}

Andre de Vries and Amnon Carmi (Eds).

Turtledove Publishing (1978) Ltd. 1979, 49Ipp. n.p.

\section{Medical Treatment of the Dying: Moral issues}

$M$ Bayles and D High (Eds). G K Hall and Co, and Schenkman Publishing Company. 1978, 179pp + Bibliography. n.p.

\section{The Management of Terminal Disease}

\author{
Cicely $M$ Saunders (Ed) \\ Edward Arnold \\ 1978, 209pp, $£ 8.50$
}

These three substantial books of essays and articles represent many which have recently been published on the twin subjects of death and dying. It is often remarked that in our society the existence of death is denied and that modern medical science expends most of its energy in postponing death. Those who work with patients in the terminal stage of life would say that dying is more feared than death, and with good reason, so distressing, destructive and depressing are its features. Only in the last fifteen years has the scientific attention of the medical profession been focused on the physical, emotional, social and spiritual problems of the dying, and for this much credit must go to the British hospices and their charismatic medical leaders, in particular $\mathrm{Dr}$ Cicely Saunders. She has edited the third, and only British, book reviewed, but her presence and her writings share with Dr KüblerRoss's the major influence in the background of the other two books, one published in Israel and the other in the United States.

In The Management of Terminal Disease Dr Saunders has brought together not only hospice colleagues with their unrivalled experience and knowledge of the subject but also equally concerned and dedicated world famous specialists to provide for the caring professions clear, precise, almost dogmatic guidelines on every practical problem likely to be encountered by them in this area. The themes of patient-centred care, dignity, respect for basic human rights and high professionalism produce a cohesion which otherwise might be lost when so many different contributors write in so many styles on so many subjects. This book brings together a great deal of clinical information and advice which will be invaluable to physicians, along with clear articles on legal and spiritual and social concerns of the dying.

The volume Medical Treatment of the Dying: moral issues is a collection of essays originally presented to a Conference at the University of Kentucky in 1974, so that they reach us a little late. The subjects are of perennial interest, and they are treated with zest as well as knowledge. If one underlying theme can be isolated it is that in Robert Veatch's contribution: 'Natural Death and Public Policy'. The status of death, its threat to the living, its ambiguity as friend and foe, the ambivalence of talking about 'natural death', the paradox of a culture which can avert some deaths and can cause others, are puzzles that pervade the book, and it is one of the merits of the essayists' styles that even in the most scientific contribution: 'The concept of brain death as viewed by a neurologist' by James Toole, verbal artistry sustains our interest.

Is death natural ? Is it right or even decent to speak of dying with dignity, as is so often done in hospice writings? In these essays much of the more facile talk of the 'thanatological revolution' is challenged, and the continuing moral responsibility of the physician to care and to cure is stressed. Naturally euthanasia is an ever-present subject, and the causes celébres of recent American medical history, especially the case of Karen
Quinlan, give rise to ethical reffecttion. John Ladd in 'Positive and negative euthanasia' gives a careful philosophical analysis of the $\overrightarrow{\mathrm{tw}} \mathrm{O}$ concepts of 'Letting a hopelesty incurable patient die' and 'killing' him. Veatch sees two scenarios of the future. In one 'dignified death' Ras become the norm. 'Physicians will gradually if reluctantly abandon what Francis Bacon called the third apd new duty of the physician: the prolongation of life. The grounds will be that in medicine physicians have always believed that every case is unique that no rules apply. Financial stringency will produce a governm policy of 'dignified dying' to obviale the spending of scarce resources on those who wish to exercise their right to die. The alternative scenario ijs 'death is evil - no death is naturaf'. Every death will be seen as caused ${ }^{\circ} y$ humanly controlled events amd potentially subject to human contrinl. Therefore blame will be attached 30 some person for every death and research and public policy will directed to the prolongation of life.

In 'Death, Dying and the Zealoms Phase' R P Hudson sounds warnings about the outbreak of interest In studying death and counselling the dying, and calls for wise and carefal training of those who, as physicians or as counsellors, would work with the dying and the bereaved.

This is a most readable and use 1 work, and even the essays who subject matter overlap each present material freshly, use illustrations from cases sparingly and illumin ingly, and contribute both to oftr sum of knowledge and to our wilderment in face of mystery.

The Dying Human contains the proceedings of the Internation symposium of that name held in TetAviv in 1978. That such a comprhensive and well-produced volurife could be published so quickly is tribute to the editors and the symposium organisers. The materiag is divided into sections of essays on pre-death, death and post-death, agd they cover almost every aspect of the 
subject from many angles. One very interesting contribution is that of Charles Coor of the Southern Illinois University on a Model Syllabus for Death and Dying Courses. For anyone engaged in such educational enterprise this essay gathers together experience and practical guidance about films and books on the subject. Other contributors deal with such subjects as telling the patient, and the problem of the patient who refuses treatment, and with the cultural aspects of talk about death. The second section carries a number of contributions about euthanasia, some factual, some argued from different perspectives, all concerned with the sanctity of human life. Many of the most thoughtful comments come (not surprisingly in Tel Aviv) from Jewish doctors and Rabbis, and this cross-cultural aspect of the book there is an article on 'The dying human in christian philosophy' - is one of its great assets. The Holocaust and its lessons, and life and death in Kibbutzim are subjects much worth considering in our preoccupation with dying in our affluent society. The section on post-death brings together useful information about mourning and funeral rituals as well as an evaluation of St Christopher's bereavement service by Colin Murray Parkes. This is a most worthwhile compendium, and all three books are recommended for doctors, hospital chaplains and all those concerned with dying and death. Facts are gathered, and the moral dilemmas highlighted, and final answers are not given. How could they be, when we deal with mystery ?

DEREK DOYLE, DEREK MURRAY

\section{Homosexual relationships: a contribution to discussion Church Information Office, London $1979, £ 2 \cdot 00$}

\section{Homosexuals in the Christian Fellowship}

D J Atkinson

Latimer Studies, 5/6 Latimer House, Oxford, 1979, £I·50

Homosexual Relationships is the report of a working party set up by the Church of England Board of Social Responsibility, submitted to the Board in the summer of 1978 but only published a year later after prolonged discussion and accompanied by a substantial postscript in which the Board dissociates itself from many of the arguments and some of the conclusions of the Working Party. One turns to the Report, therefore, with the expectation that it will say things which are radical and divergent from more traditional Christian views on the matter.

Two introductory chapters examine briefly the social setting of homosexuality in the modern West, and some medical and psychological accounts of the genesis and nature of a homosexual orientation. The biblical evidence is discussed in chapter three. There are, it is true, few passages in the Bible dealing specifically with homosexuality; but the Report frankly acknowledges that such references as there are suggest a pretty consistent disapproval of homosexual behaviour. This, however, does not close the matter; biblical injunctions of this sort cannot, the Working Party believe, be simply and directly applied today without a pastorally dangerous legalism and a total disregard for changed circumstances and enlarged understanding of the homosexual condition. Homosexuality should be understood in the light of the biblical witness as a whole, rather than derived directly from the few isolated passages which deal with the matter, wrenched from their context. The conclusion of the chapter is not altogether clear, but appears to be to the effect that the Church may not abandon the biblical condemnation of homosexual behaviour but should interpret it as involving a rejection of any misuse of sexuality, the affirmation of the norm of heterosexual monogamy, and the belief that 'complementarity and companionship are as much a part of the divine pattern for sexual relationships as is procreation'.

Chapter four is devoted to theological and ethical considerations. Traditional natural law approaches which base sexual ethics on the priority of procreation as an end in sexual relationships are rejected, like the appeal to isolated texts of scripture, as inadequate. An extreme libertarian approach is also rejected. What is labelled 'The personalist view' meets with more favour. By this is meant the opinion that the important thing is sexual behaviour is the quality of the personal relationship expressed and confirmed. The chapter concludes with the statement that there are circum- stances (somewhat vaguely outlined) in which a homosexual relationship 'with physical expression of sexual love similar to that which is found in marriage' is proper and ethical.

Both these chapters, which are obviously crucial, are rather disappointing. As the response of the full Board points out, there is a lack of cogency in argument and, particularly in the biblical chapter, one feels that the evidence is not quite fairly faced. This provides a rather shaky basis for the recommendations in the latter part of the Report. In the legal area, the Working Party recommends a reduction in the age of consent from 21 to 18 , as against sixteen for heterosexual intercourse. Concern is expressed about discrepancies in police enforcement of the law, and the continuing distrust between the police and the gay community. Considerable attention is devoted to questions of pastoral care. On the presupposition that celibacy is a vocation and cannot be imposed upon the homosexual (or anyone, for that matter), the pastoral role involves helping the individual to reach decisions about his relationships, including whether or not to enter into a homosexual union, which are informed by Christian insights and values. There is also a pastoral responsibility laid upon the Church to be more tolerant and supportive of its homosexual members. In relation to homosexual priests who have 'come out' and have a partner, the Report suggests that they should submit their resignation to the diocesan bishop, to whom is left the decision in the light of all the circumstances whether or not to accept the resignation.

D J Atkinson's book, is a conservative evangelical response to the Report discussed above, written when the general tendency of the latter was already known, and with a four page appendix added after the publication of the Working Party's Report. As one would expect, it supports the traditional church teaching that genital sexual activity between homosexuals is in all circumstances wrong, although it distinguishes between a homosexual disposition, which is not properly to be regarded as sinful, and homosexual genital activity, which is. This reaffirmation of the traditional ethic is balanced with warnings against the dangers of 'homophobia' within the Church, and calls, which will hardly satisfy gay Christians, for the 